Book Review

\title{
James, George G. M., Stolen Legacy: The Egyptian Origins of Western Philosophy ${ }^{1}$
}

Kristian Urstad

$\mathrm{F}$ irst published in 1954, and most recently reprinted in 2010, the selfstated aim of James' book is to establish improved race relations in the world by revealing an underlying truth concerning the contribution of the African continent to the rest of the world. It is an attempt to show that the true authors of Greek philosophy were not the Greeks, but the Egyptians. This theft of the African philosophical legacy by the Greeks has led to the mistaken opinion that the African continent has made no intellectual contribution to civilization - a misrepresentation that has become the root of racial prejudice. By bringing this information to the attention of the world, James hopes to remedy these prejudices which have corrupted human relations.

James' aim in Chapter One is to try to show that all the Ionian and Italian philosophers - Pythagoras, Thales, Democritus, and so on - obtained their education from Egyptian priests or became familiar with the teachings of the so-called Egyptian Mysteries well before they settled down and published their philosophies. In effect, the author argues that what these philosophers were disseminating was really the thoughts and doctrines of these Egyptians.

James' objective in Chapter Two is to argue that, since the period of Greek philosophy (640-322 B.C.) was a time of continual internal and external wars, it could not have provided a suitable environment for the production of philosophers. The Persian conquests, the Leagues and the Peloponnesian wars are all mentioned as troublesome conditions of this period in Greek history.

The author claims that the development of philosophical thought requires an atmosphere which is free from strife and worry. Since this period was exactly the opposite to one of ease and tranquility, it could not be expected to have produced any philosophy of its own.

In Chapter Three, James discusses the agreement or circumstances of identity between Egyptian and so-called Greek philosophical thought. Two points of agreement are stressed: the cultivation of the sciences and the life of virtue. He asserts that Socrates and other Greek philosophers offended the Athenian government because they pursued the study of astronomy and

${ }^{1}$ USA: Feather Trail Press, 2010. 
geology. Since the study of these sciences was a necessary condition to membership in the Egyptian Mystery System, James concludes that Socrates and others were fulfilling a required condition to this membership. The author also claims to locate the origin of Greek ethical thought, and in particular, Plato's four cardinal virtues, in the ethical system (soul attributes) of the Egyptian Mysteries.

Chapter Four is devoted to a discussion on the education of the Greeks by the Egyptians. James claims that Egypt, in ancient times, was supreme in the leadership of civilization, and that students from all parts, including Greek ones, flocked to that land, seeking education and admission into her Mystery System. Among the Greek students were Thales (who picked up Egyptian science), Pythagoras (who picked up the doctrine of metempsychosis and mathematics), Democritus (who studied Egyptian science), and Plato (who received instruction from Egyptian priests). Though history seems to be silent on thinkers like Socrates and Aristotle with respect to any travels to Egypt, the author claims that this, in part, is because students of the Mystery System concealed their movements.

In Chapters Five and Six, James goes into more detail with regards to the Egyptian origins of the doctrines of the so-called Greek philosophers. The author begins with a discussion of the teachings of the earlier and later Ionian schools, the Pythagoreans, and the Eleatics. Although the early Ionic philosophers have been given the credit of teaching the doctrines that all things originate from water, air, and so on, it is clear, James argues, that these were not novel ideas and that the Ionians drew their teachings from earlier Egyptian sources. The doctrines of Pythagoras, in particular, the immortality of the soul and the Supreme Good or summum bonum, are also claimed to be directly taken from the Egyptian Mysteries. Democritus too, it is said, taught nothing new, but simply what he had learned from the Egyptians. The author alleges that Democritus simply could not have written the large list of books ascribed to him and so must have come to possess them (and their doctrines) as a result of Alexander the Great's conquest and looting of the Royal Egyptian Library and temples.

James argues that Socrates, Plato and Aristotle too, are borrowing from Egyptian doctrines. Socrates' concepts of the Supreme Good and selfknowledge, and his commitment to astrology and geology are derived directly from the Egyptian Mysteries, or indirectly from the Pythagoreans. The author also claims that Socrates' early obscurity and life of poverty coincides with the requirements of the Mystery System of Egypt, which exacted the vows of secrecy and poverty from all Initiates. Plato's doctrines, especially the theory of ideas, the cardinal virtues and that of the ideal state, also point to Egyptian origin. In fact, James contends that Plato was not the author of the majority of dialogues commonly attributed to him, including the Republic. True authorship belongs to the Egyptians. Finally, James argues that Aristotle's doctrines, including that of the soul, the origin of the world and the existence of God, were the result of the books he obtained from the Egyptian library, after it had been ransacked and looted by Alexander and his party (to which Aristotle 
belonged). Part of James' argument is that Aristotle could not have picked up his scientific knowledge from Plato, who he claims was incompetent with respect to this material. Instead, the author contends that the vast number of scientific books Aristotle allegedly wrote are in fact not his, rather, they are books he carried away from the Alexandrian Library.

Skipping over (the very brief) Chapters Seven and Eight, James, in his final chapter, urges us to disseminate this truth - that the Greeks stole the legacy of the African continent and called it their own - through a system of re-education. False praise of the Greeks must be removed from the textbooks of our schools and colleges. We must do a better job of showing the world that the doctrines of the so-called Greek philosophers originated from the ancient Mystery System of North Africa. To carry out this world-wide crusade, James recommends 'Stolen Legacy' for adoption and study in our schools and universities. This, he believes, would be effective in the creation of a much needed racial reformation.

Though one can appreciate what James was trying to do for African people and tradition, especially given the context in which this work was written, this is a book wrought with historical inaccuracies, sketchy dating, dubious referencing, and philosophical misunderstandings. Although scholarly impropriety abounds, I limit myself here to a few comments.

James' aforementioned claim, in Chapter Two, that the Greeks could not be expected to produce philosophy because philosophy requires a suitable environment is simply not convincing. While this period in Greek history was certainly a turbulent one, philosophical production was usually the result of a leisure and wealthy class, a class which had the time and means to reflect and write. On the other hand, an environment wrought with disturbance and worries need not always provide an obstacle to philosophical production. Sartre began work on his Being and Nothingness while he was a prisoner of war and The Consolation of Philosophy was written by Boethius in the period leading up to his brutal execution.

In Chapter Five, James claims that Democritus did not write those books commonly attributed to him. Instead, he came to possess them from Anaxarchus, who had brought them back from the Egyptian Library, a library sacked and looted during Alexander's conquest of Egypt (a campaign which Anaxarchus was a part of). The author's claim here is altogether historically erroneous. Democritus was born eighty or so years before Anaxarchus and would have been dead forty years before Anaxarchus' return to Ionia. Similar cases of (glaring) historical negligence are rife throughout James' book.

In Chapter Six, the author alleges that Aristotle could not have learned any scientific material from Plato since his teacher was incompetent in this regard. Instead, it is claimed that any scientific knowledge Aristotle had was acquired through his time with Egyptian priests and from Egyptian books carried away from the Alexandrian Library. Again, this is simply not true. Aristotle's vision of the cosmos, for instance, owes much to not only his Presocratic predecessors, but to Plato's Timaeus. Part of James' claim here is that Aristotle did not spend twenty years of his life as a pupil of Plato in the 
Academy but rather spent those years under the tutelage of Egyptian priests. Yet, again, many of Aristotle's works of youth - some in the form of fragments, others, more complete - point to strong Platonic influence, both in terms of dialogue form and expression of (similar) content. This, and the plethora of confirming testimony, suggests that there is no plausible reason to believe that Aristotle did not spend two decades as a student in Plato's Academy.

At heart, James' book is a plea for justice and reformation, a call to turn the tide of racism washing over his time. However, what Stolen Legacy is not, is a genuine work of scholarship. I cannot see it sparking or encouraging further inquiry, and it is not a book I would recommend.

Department of Philosophy, University of the Fraser Valley, Canada 